\title{
Designing Mathematics Learning Media Based on Mobile Learning for Ten Graders of Vocational High School
}

\author{
Budi Murtiyasa $^{1}$, Indah Miftakul Jannah², Sri Rejeki ${ }^{1, *}$ \\ ${ }^{1}$ Department of Mathematics Education, Universitas Muhammadiyah Surakarta, Indonesia \\ ${ }^{2}$ Department of Informatics Engineering Education, Universitas Muhammadiyah Surakarta, Indonesia
}

Received July 20, 2020; Revised August 27, 2020; Accepted September 29, 2020

\section{Cite This Paper in the following Citation Styles}

(a): [1] Budi Murtiyasa, Indah Miftakul Jannah, Sri Rejeki, "Designing Mathematics Learning Media Based on Mobile Learning for Ten Graders of Vocational High School," Universal Journal of Educational Research, Vol. 8, No. 11, pp. 5637- 5647, 2020. DOI: 10.13189/ujer.2020.081168.

(b): Budi Murtiyasa, Indah Miftakul Jannah, Sri Rejeki (2020). Designing Mathematics Learning Media Based on Mobile Learning for Ten Graders of Vocational High School. Universal Journal of Educational Research, 8(11), 5637 - 5647. DOI: 10.13189/ujer.2020.081168.

Copyright $(2020$ by authors, all rights reserved. Authors agree that this article remains permanently open access under the terms of the Creative Commons Attribution License 4.0 International License

\begin{abstract}
The development of information technology plays an essential role in supporting learning activities in all subjects, including mathematics. In mathematics learning, teachers usually use conventional media, such as printed textbooks and paper-based students' worksheets. Regarding this issue, an innovation of mathematics learning media based on information technology is needed to be developed. Therefore, this study aims to design learning media based on mobile learning. This study is a research and development $(\mathrm{R} \& \mathrm{D})$ study applying the $4 \mathrm{D}$ development model (Define, Design, Develop, Disseminate). This study's subjects are students in the tenth grade of a private vocational high school in Central Java, Indonesia. The results of this study can be described as follows: 1) the rating of media experts with an average value of 67.5 is included in the excellent category; 2 ) the material experts' assessment with an average score of 75 is included in the excellent category; 3) the students' evaluation with an average grade of 70,119 is included in the excellent category. The assessment was obtained from the SUS (System Usability Scale) questionnaire. Moreover, based on the analysis of a pre-experimental design, it can be concluded the media improve students' scores in the topic of matrix operations.
\end{abstract}

Keywords Mobile Learning, Matrix Operations, Smart Apps Creator

\section{Introduction}

Previous studies found that technology is a powerful tool to improve the quality of education. The use of technology could improve students' positive attitude towards mathematics in terms of self-directed learning [1], self-efficacy and motivation [2], as well as enjoyment and engagement in learning mathematics [3], [4]. Furthermore, the literature shows the critical role of technology in enhancing students' mathematics learning achievement [1]-[4]. Those findings imply an increase in the number of studies in designing mathematics learning activities, integrating technologies in various forms.

According to Borba [5], during the last decade, there are five forms of digital technology applied in mathematics education, namely mobile technologies, massive open online courses (MOOCs), digital libraries and designing learning objects, collaborative learning using digital technology, and teacher training using blended learning. Among the five forms, using mobile technologies provides more space for students to create and explore their knowledge, particularly in mathematics inside and outside the classroom [6]. Therefore, designing learning media based on mobile learning is necessary to support students' learning mathematics. 
Mobile learning refers to mobile or wireless devices for education while on the move [7]. However, mobile learning's pedagogical aspect involves not only the use of portable devices, but also the ability to learn in different contexts (beyond the classroom, for example) through intertwined interactions with people, content, and devices [8]. In the field of mathematics, mobile learning has been applied to various levels of education and topics [1], [3], [6], [9].

Matrix is one of the mandatory topics usually learned by students in upper secondary school. The content consists of the definition of matrix, kinds of matrix, matrix transpose, matrix similarity, and matrix operations [10]. The topic contributes to computing, geology, economics, and else [11]. However, students' motivation to learn the topic is not good.

In general, students' motivation in learning mathematics is at a low level [12], [13], as well as students' level in solving mathematics problems [14]. In the Indonesian context, studies found that the low level of motivation is mainly occurred for vocational high school students [15],
[16]. Vocational high school is a type of high school education that focuses on preparing students with technical skills to enter a specific job.

Therefore, this study aims to develop learning media based on mobile learning using Smart Apps Creator and assessing the effectiveness of the learning media developed on students' mathematics learning achievement.

\section{Methods}

This study applied Research and Development (R\&D) as the research approach with the 4D Model (Define, Design, Develop, and Disseminate). The researchers conducted the stages of Define and Design based on existing literature related to the research topic. Media experts and material experts conducted the phase of Develop. Lastly, the Disseminate stage was done using mobile learning media in real classroom mathematics and assessing its effectiveness.

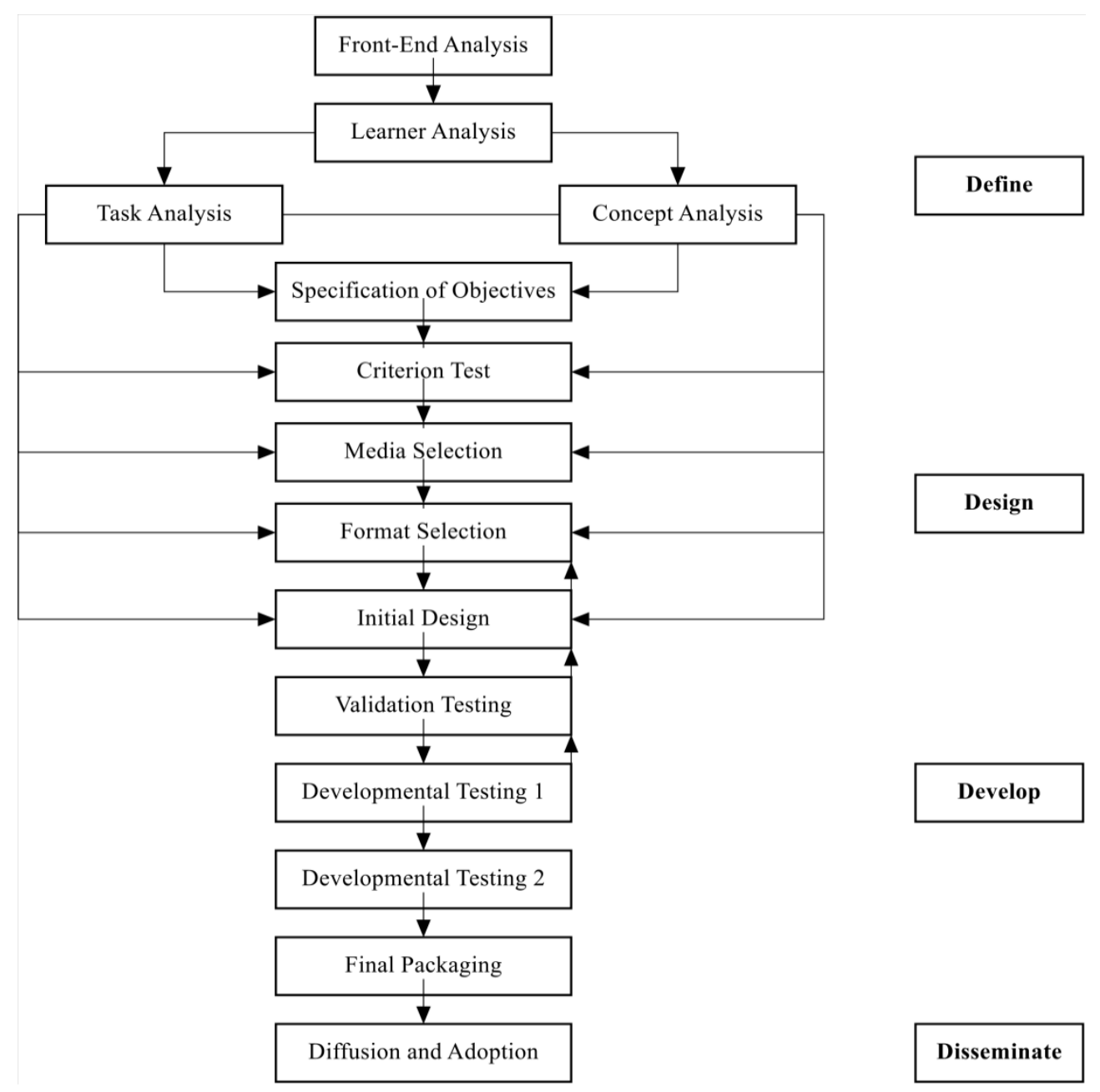

Figure 1. The $4 \mathrm{D}$ Model 


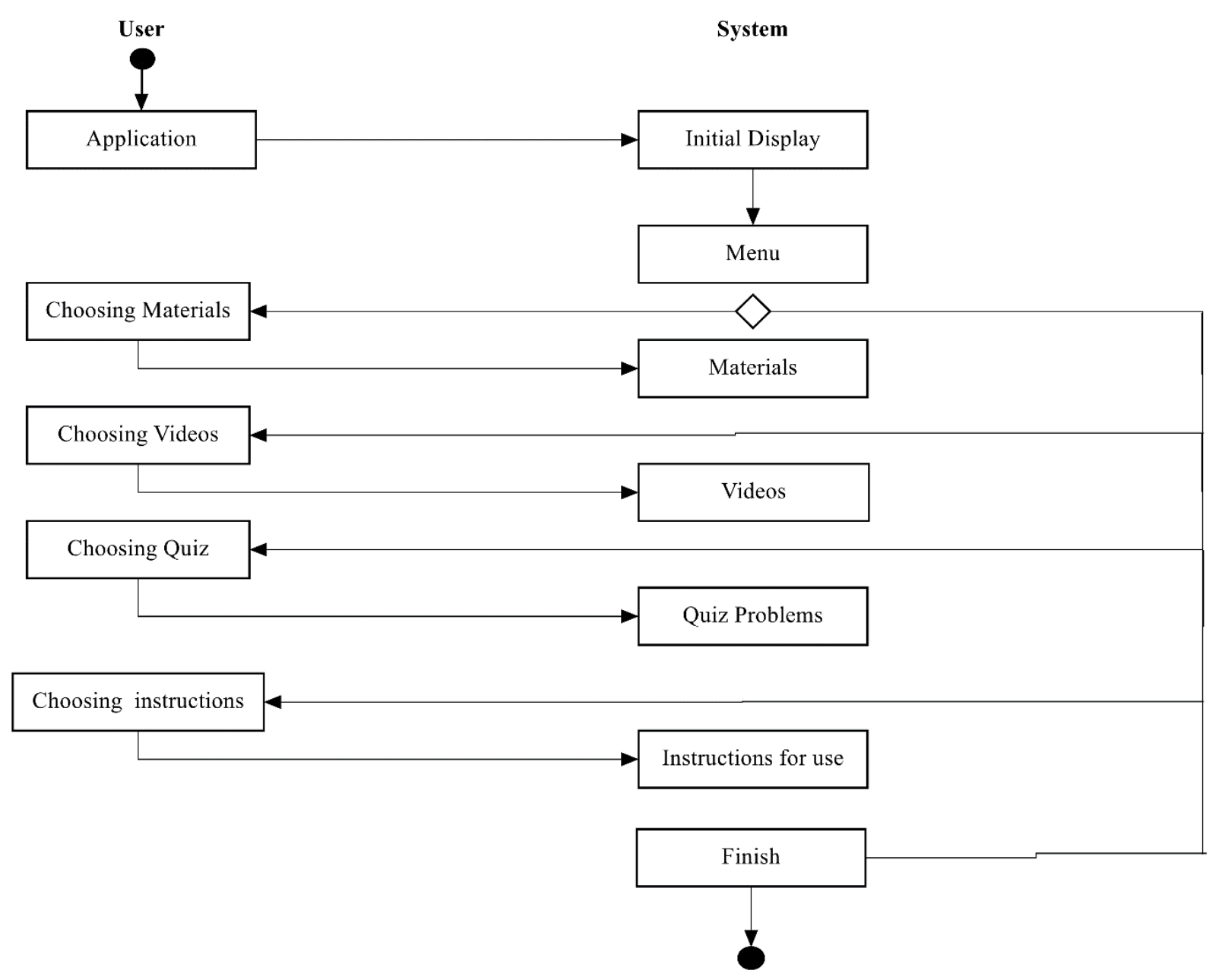

Figure 2. Activity Diagram

Figure 1 shows the flow of the 4D Model. The Defining stage is started with front-end analysis and ended with the specification of objectives. Afterward, the Designing stage is started with a criterion test and ended with the initial design. The Development stage is begun with validation testing and ended with the final packaging. Lastly, the Dissemination stage consists of diffusion and adoption.

Whereas Figure 2 describes the activity diagram, which is a flow of media use. In this media, there are three menus, namely: material, videos, and quizzes. The material menu has four sub-materials, the video menu has five sub-video content, and the quiz menu discusses questions.

The data analysis conducted using a qualitative and quantitative approach. The qualitative data were obtained from notes and feedbacks by media experts and material experts for the development stage of the mobile learning media. Whereas the quantitative data were obtained from students' mathematics achievement test and a questionnaire that was assessed by students.

Questionnaire data from the media experts, the material experts and students will then be processed into the final results. The formula used is taken from the formula of Brooke [17]:

Score SUS $=((\mathrm{Q} 1-1)+(5-\mathrm{Q} 2)+(\mathrm{Q} 3-1)+(5-\mathrm{Q} 4)+$ $(\mathrm{Q} 5-1)+(5-\mathrm{Q} 6)+(\mathrm{Q} 7-1)+(5-\mathrm{Q} 8)+(\mathrm{Q} 9-1)+(5-\mathrm{Q} 10) * 2.5)$

\section{Results and Discussion}

The results and discussion part will be broken down into five sub-sections. The first sub-section describes the define and development stage, the second and third sub-sections explain media and material experts' assessment, respectively. Morever, the fourth sub-section describes the results of the experimental study.

\subsection{The Define and Design Stages}

The define and design stages were conducted by following the storyboard that has been made at the beginning. The following are the results of the development of mobile learning media: 


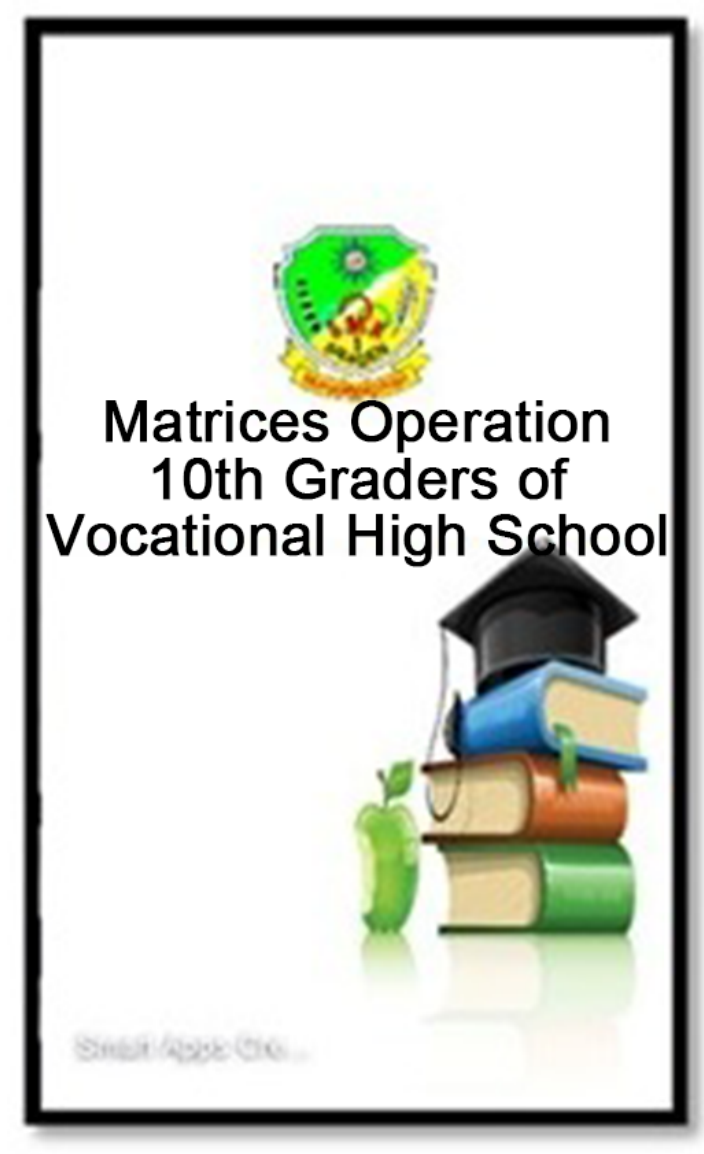

Figure 3. The Initial Display

Figure 3 shows the initial appearance of the mobile learning media. There are school logo, the title of the topic (Matrices Operation), and the target group $\left(10^{\text {th }}\right.$ Graders of Vocational High School).

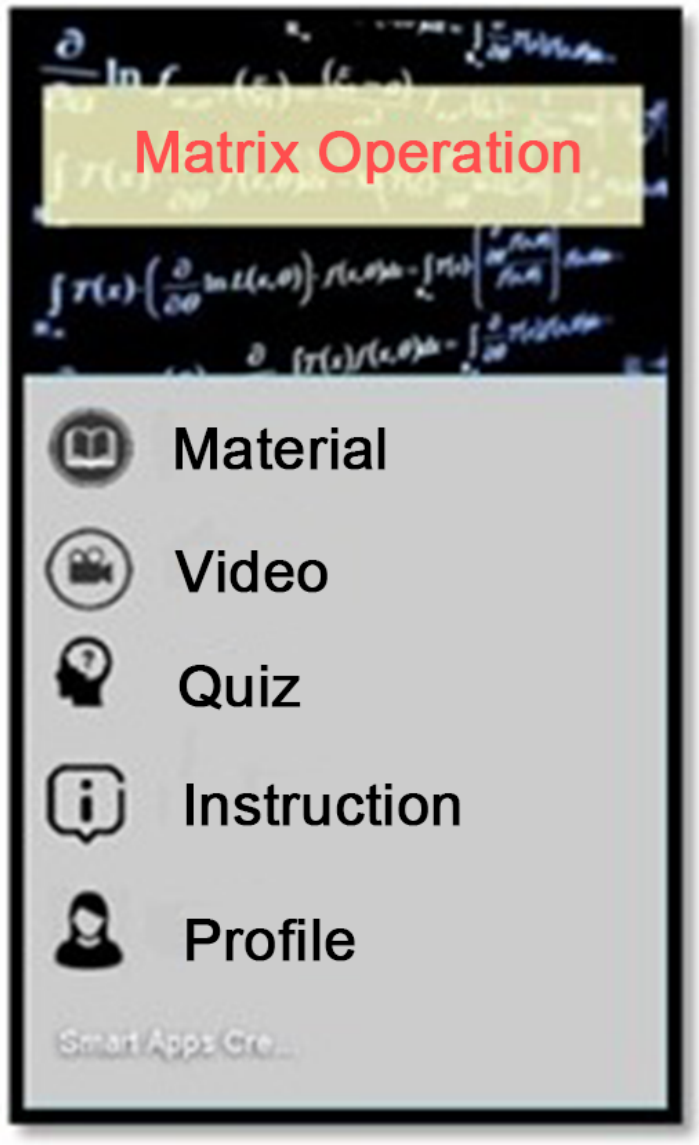

Figure 4. The Menu Display

Figure 4 shows the menu display. On this menu, there are five features, namely material, video, quiz, instruction, and profile. The material feature contains the content of matrix operations; the video feature contains five learning videos related to matrix operations. The quiz feature consists of 10 multiple choice items about matrix operations problems. In this quiz feature, if the students answer correctly, to get a value of 10 and a checkmark will appear if students answer incorrectly the value of 0 and a cross will look. At the end of the quiz, grades, and discussion of the quiz question will appear. The instructions feature includes instructions for using the application, and the profile feature contains the application's self-data maker. 

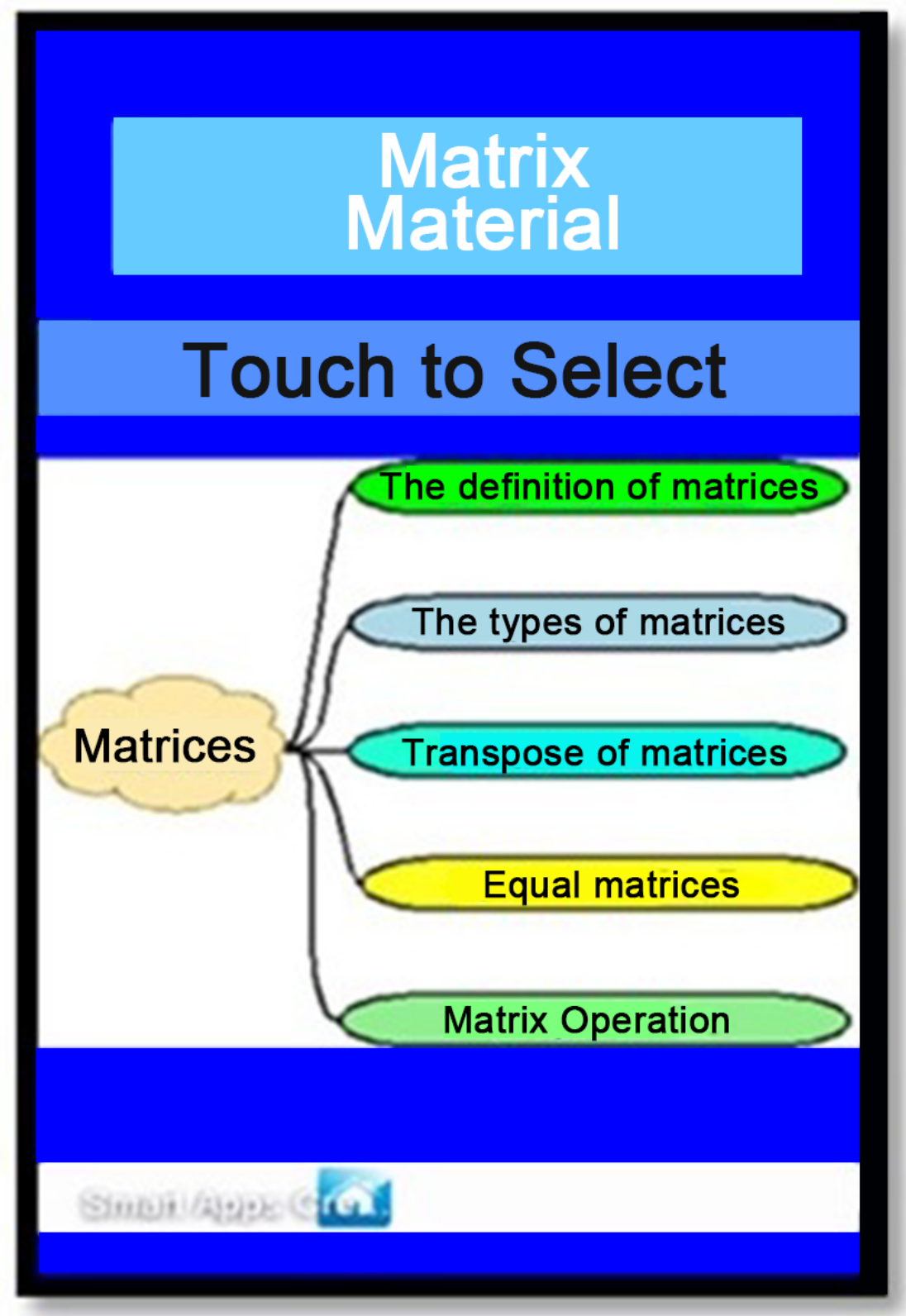

Figure 5. The Display of the Material Sub-menu

Figure 5 shows the display of the material sub-menu. In this submenu, there is a running text that informs the users to touch the mindmap to select the material they want to access. This sub-menu provides the contents of several topics, namely, the definition of matrices, the types of matrices, transpose of matrices, equal matrices, and matrix operations. At the bottom of the display, there is a home icon that can bring back the users to the main menu.

Like the material sub-menu, the video sub-menu also provides the video Figure 6 is the display of the video sub-menu. In this sub-menu, there is also a running text that functions to tell the user to touch the mindmap to select material. Students can choose the video they want to be seen. In this submenu, there are several learning videos, namely, matrix notation and order, matrix type, matrix transpose, matrix addition and subtraction, and matrix multiplication. 


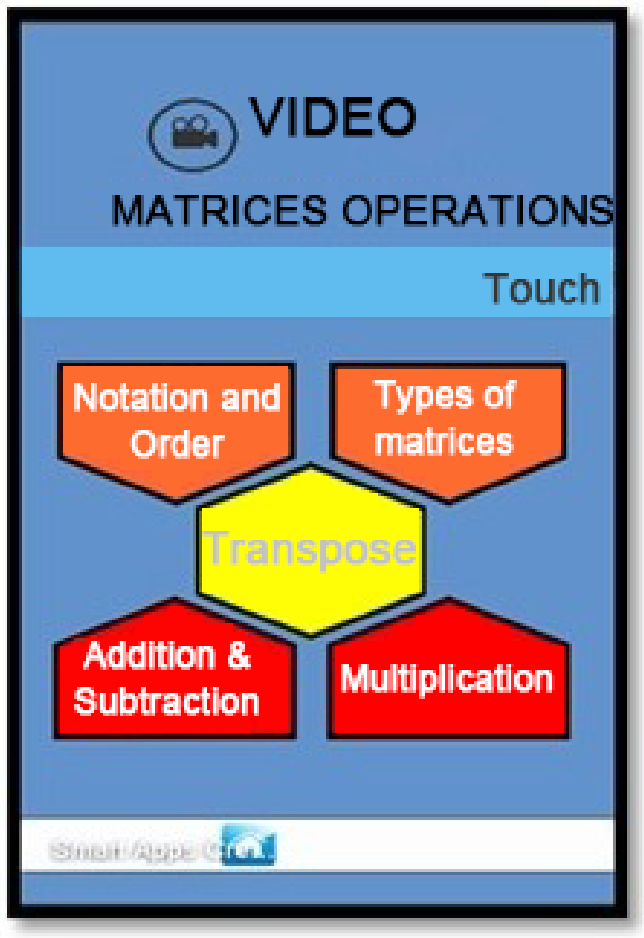

Figure 6. The Display of Video Sub-menu

Figure 7 is a display of the questions provided in the quiz. Students work on the quiz independently. The quiz will be worth ten if students answer correctly, and if students answer incorrectly, it has a value of 0 .

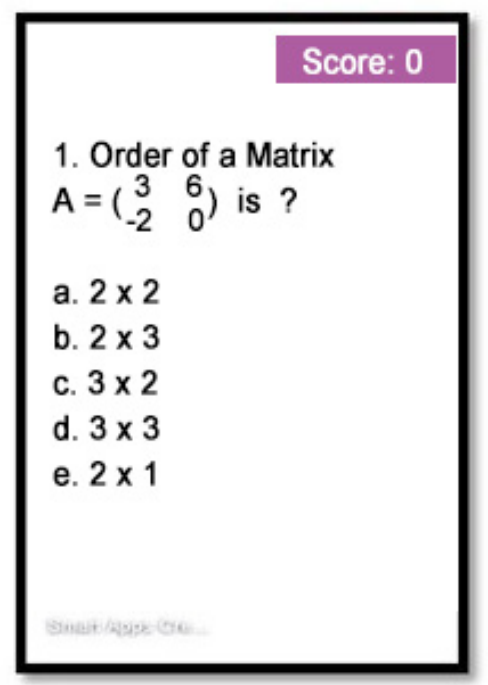

Figure 7. An Example Problems Provided in Quiz
Figure 8 shows the final score of the quiz, where students can find out the overall value of the quiz done. In this view, students can choose the retry menu and discuss the questions if the retry menu will again try the quiz. When students choose the question discussion menu, a question discussion will appear along with the answer key.

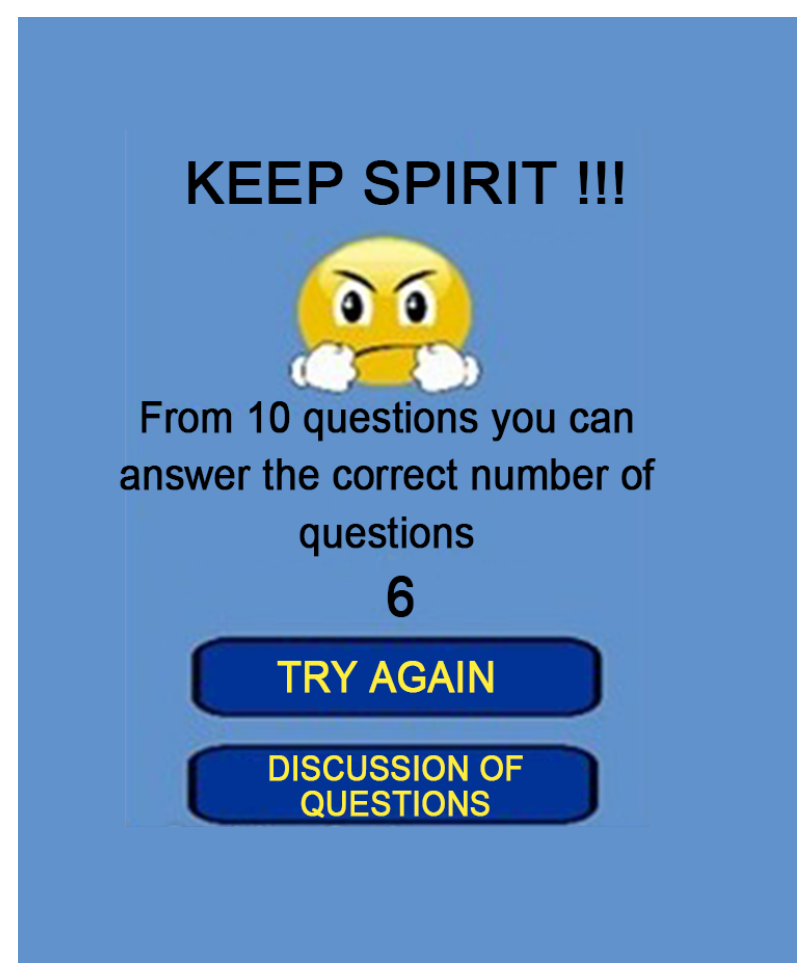

Figure 8. The Display of Quiz Score

Figure 9 is a display of discussion of questions, on the menu of discussion of these questions, there are answer keys and a discussion of the whole problem. On this menu, students are better able to understand quiz questions. 


\section{Discussion of Quiz Questions}

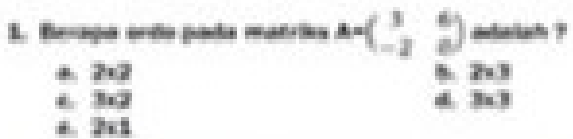

Dit
i. |at
4. $\left.\begin{array}{ll}1 & 4 \\ 4 & 1\end{array}\right]$
1. Itit
$4\left(\begin{array}{lll}1 & 1 & 1\end{array}\right)$

$=\left(\begin{array}{cc}1 & 1 \\ 1 & 1 \\ 4 & -1\end{array}\right)$

ibatuen

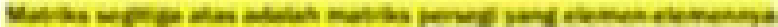

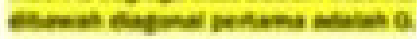

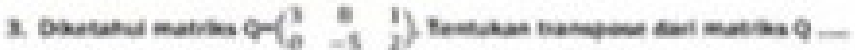
$+\left(\begin{array}{cc}1 & 2 \\ 1 & -4 \\ -1 & 1\end{array}\right)$
\& $\left[\begin{array}{lll}1 & a & 1 \\ 1 & -1 & 1\end{array}\right)$
i. $\left(\begin{array}{cc}7 & 5 \\ -1 & 1\end{array}\right)$
$+\left[\begin{array}{lll}1 & -1 & 1\end{array}\right.$

a $\begin{array}{ccc}-4 & 1 \\ 1 & 1\end{array}$

a

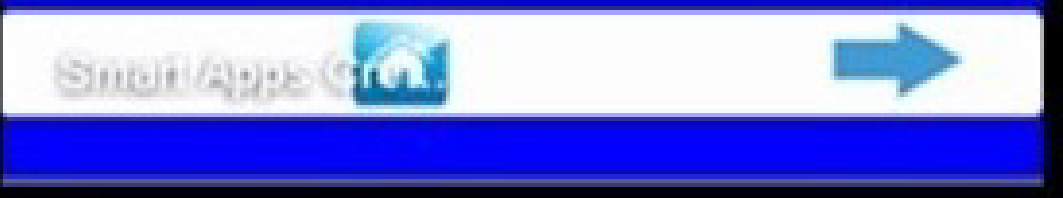

Figure 9. The Feedback of Quiz

\subsection{The Assessment from Expert in Learning Media}

The assessment of media experts was carried out by a lecturer in Information Engineering Education, Muhammadiyah University, Surakarta. The results of the evaluation are as follows:

Table 1. Media Expert Ratings

\begin{tabular}{|c|c|c|c|c|c|c|c|c|c|c|c|}
\hline Respondent & $\mathrm{Q}_{1}$ & $\mathrm{Q}_{2}$ & $\mathrm{Q}_{3}$ & $\mathrm{Q}_{4}$ & $\mathrm{Q}_{5}$ & $\mathrm{Q}_{6}$ & $\mathrm{Q}_{7}$ & $\mathrm{Q}_{8}$ & $\mathrm{Q}_{9}$ & $\mathrm{Q}_{10}$ & Score SUS \\
\hline $\mathrm{R}_{1}$ & 3 & 3 & 2 & 3 & 3 & 2 & 3 & 2 & 3 & 3 & 67,5 \\
\hline
\end{tabular}


Table 1 shows the results and the average media expert evaluation questionnaire conducted by one lecturer. From the above table, it can be concluded that the scores from surveys 1-10 with an average value of 67.5. In the classification of acceptability ranges, grade scale, and adjective ratings are included in the marginal high, grade $\mathrm{D}$, and good categories. This result means that learning media is appropriate and more efficient.

\subsection{The Assessment from Expert in Mathematics Content}

The material expert assessment was carried out by one teacher at a private vocational high school in Sragen, Central Java, Indonesia. The results of the evaluation are as following table 2 .

In Table 2 results from of the assessment of material experts conducted by subject teachers of a private vocational high school in Sragen, Central Java, Indonesia. The chart above shows the questionnaire's value that has been filled out by subject teachers with an average result of 75. The average value in the classification of acceptability ranges, grade scale, and adjective ratings are included in the categories of acceptable, grade $\mathrm{C}$, and excellent, meaning the material in the learning media by basic competencies and core expectations so that students can accept them.

\subsection{The Students' Achievement Test}

Figure 10 shows the comparison of learning outcomes obtained from the pretest and posttest scores. The pretest is conducted before learning activities using learning media development. After working on the pretest, students try to use learning media. Students work on the posttest after trying to use learning media. So, it can be concluded that by using mobile learning media, there is an increase in students' value.

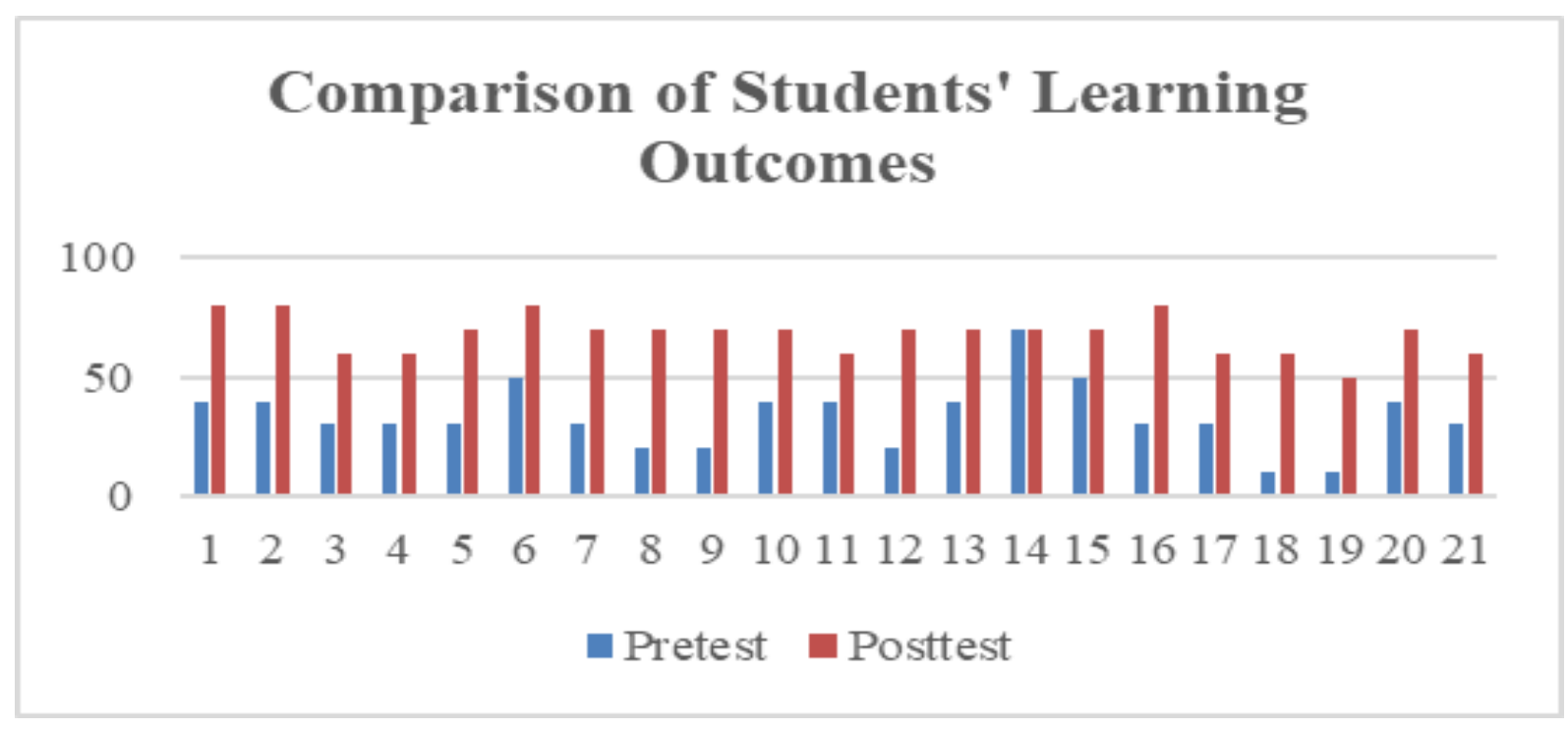

Figure 10. Students' Learning Outcomes

Whereas, Table 3 describes the result of questionnaire grade X students of SMK Muhammadiyah 1 Sragen with a total of 21 people. From the table above, it can be seen that the average student questionnaire score was 70.119. In classifying the value of acceptability ranges, grade scale, and adjective ratings included in the categories acceptable, grade $\mathrm{C}$, and good, meaning that this learning media can be accepted by students to increase student learning motivation.

Table 2. Expert Material Assessment

\begin{tabular}{|c|c|c|c|c|c|c|c|c|c|c|c|}
\hline Respondent & $\mathrm{Q}_{1}$ & $\mathrm{Q}_{2}$ & $\mathrm{Q}_{3}$ & $\mathrm{Q}_{4}$ & $\mathrm{Q}_{5}$ & $\mathrm{Q}_{6}$ & $\mathrm{Q}_{7}$ & $\mathrm{Q}_{8}$ & $\mathrm{Q}_{9}$ & $\mathrm{Q}_{10}$ & $\begin{array}{c}\text { Score } \\
\text { SUS }\end{array}$ \\
\hline $\mathrm{R}_{1}$ & 3 & 3 & 3 & 3 & 3 & 3 & 3 & 3 & 3 & 3 & 75 \\
\hline
\end{tabular}


Table 3. Students' Questionnaire Results

\begin{tabular}{|c|c|c|c|c|c|c|c|c|c|c|c|}
\hline Respondent & $\mathrm{Q}_{1}$ & $\mathrm{Q}_{2}$ & $\mathrm{Q}_{3}$ & $\mathrm{Q}_{4}$ & $\mathrm{Q}_{5}$ & $\mathrm{Q}_{6}$ & $\mathrm{Q}_{7}$ & $\mathrm{Q}_{8}$ & $\mathrm{Q}_{9}$ & $\mathrm{Q}_{10}$ & $\begin{array}{c}\text { Score } \\
\text { SUS }\end{array}$ \\
\hline $\mathrm{R}_{1}$ & 4 & 3 & 4 & 1 & 3 & 2 & 3 & 3 & 3 & 3 & 72,5 \\
\hline $\mathrm{R}_{2}$ & 3 & 3 & 4 & 1 & 3 & 2 & 2 & 2 & 4 & 2 & 65 \\
\hline $\mathrm{R}_{3}$ & 3 & 3 & 3 & 2 & 4 & 3 & 3 & 2 & 4 & 3 & 75 \\
\hline $\mathrm{R}_{4}$ & 3 & 3 & 3 & 3 & 3 & 2 & 3 & 3 & 3 & 2 & 70 \\
\hline $\mathrm{R}_{5}$ & 3 & 3 & 3 & 2 & 3 & 3 & 3 & 3 & 4 & 2 & 72,5 \\
\hline $\mathrm{R}_{6}$ & 3 & 3 & 3 & 1 & 3 & 2 & 3 & 3 & 3 & 3 & 67,5 \\
\hline $\mathrm{R}_{7}$ & 3 & 3 & 3 & 2 & 3 & 3 & 3 & 2 & 3 & 2 & 67,5 \\
\hline $\mathrm{R}_{8}$ & 3 & 3 & 3 & 2 & 3 & 3 & 2 & 2 & 3 & 2 & 65 \\
\hline $\mathrm{R}_{9}$ & 3 & 3 & 3 & 2 & 3 & 3 & 2 & 3 & 3 & 2 & 67,5 \\
\hline $\mathrm{R}_{10}$ & 3 & 3 & 2 & 1 & 3 & 2 & 3 & 3 & 3 & 3 & 65 \\
\hline $\mathrm{R}_{11}$ & 3 & 4 & 3 & 2 & 3 & 3 & 3 & 2 & 3 & 3 & 72,5 \\
\hline $\mathrm{R}_{12}$ & 3 & 4 & 3 & 2 & 3 & 2 & 3 & 3 & 3 & 3 & 72,5 \\
\hline $\mathrm{R}_{13}$ & 3 & 3 & 4 & 2 & 3 & 3 & 3 & 2 & 3 & 3 & 72,5 \\
\hline $\mathrm{R}_{14}$ & 3 & 3 & 3 & 1 & 3 & 3 & 3 & 3 & 3 & 2 & 67,5 \\
\hline $\mathrm{R}_{15}$ & 3 & 3 & 3 & 1 & 3 & 3 & 3 & 3 & 3 & 2 & 67,5 \\
\hline $\mathrm{R}_{16}$ & 3 & 3 & 3 & 1 & 3 & 2 & 3 & 3 & 3 & 3 & 67,5 \\
\hline $\mathrm{R}_{17}$ & 4 & 3 & 4 & 1 & 4 & 3 & 3 & 3 & 4 & 3 & 80 \\
\hline $\mathrm{R}_{18}$ & 3 & 3 & 2 & 3 & 3 & 3 & 3 & 2 & 3 & 3 & 70 \\
\hline $\mathrm{R}_{19}$ & 3 & 2 & 4 & 3 & 3 & 2 & 4 & 2 & 4 & 3 & 75 \\
\hline $\mathrm{R}_{20}$ & 3 & 3 & 3 & 1 & 3 & 3 & 3 & 3 & 3 & 3 & 70 \\
\hline $\mathrm{R}^{21}$ & 3 & 3 & 3 & 1 & 3 & 3 & 3 & 3 & 3 & 3 & 70 \\
\hline
\end{tabular}

\subsection{Discussion}

The product developed is mathematics learning media based on mobile learning. The learning media trains students to utilize technology in the world of education. The purpose of developing this media is to make students easily understand the material presented by the teacher. This mobile learning media is one way to attract students' learning interests so that students can learn independently. Mobile learning media in a private vocational high school in Sragen, Central Java, Indonesia, has never been used, so this learning media is included as an innovation in the existing learning process.

In a study conducted by Rubhan [18], using Macromedia Flash software gets students' responses with an average value of 3.61 included in the category of very interesting. Whereas this study used smart apps creator software and received a good response from students. There is an increase in the value obtained by students before and after using learning media.

The development model in this product uses the 4D development model (define, design, develop, disseminate) used by Fredyana [19]. The last stage in the research model is that dissemination has not yet been carried out because of limitations in the study. In developing this product, many inputs from media experts and material experts are then used as a reference as an improvement.

The development of learning media begins with observations to find out the needs of students. The field study was conducted on 21 grade $\mathrm{X}$ students of a private vocational high school in Sragen, Central Java, Indonesia. The number of respondents used in previous researchers different. As did by Mohammad [20], 118 respondents were involved so that more suggestions were received.

This mobile learning media can be used offline so that students save more money on using this media. The spread of instructional media is currently still done manually by spreading via data transfer. In research conducted by Rihandoko [21], the use of developed media can be used online, so students need cellular data to access it. In his study, Rihandoko [21] uses the Appypie application to create learning media. This application can be used online.

This learning media was developed to help students learn mathematics, especially in the basic competencies of matrix operations. Using this media, students can practice the questions, understand the material in the form of video, and discuss the questions. Suen \& Fung [22], in his research, develops mobile learning of English literary content that is conveyed by a famous poet and writer named William Shakespeare. The media made contains work that has been produced. Harlis et al. [23] also developed mobile learning applications for biology subjects in their development, taking the subject of monera taxonomy and protists in algal material. The learning media of mobile learning is currently being developed because it is more effective and efficient. It helps educators deliver content so that students are more aware of the material presented and more effective in the use of devices for school-age children.

The subject of this learning media development is for grade X students of Vocational High Schools (SMK). In vocational students, the use of devices at school is permissible as long as they are used for learning, in 
schools where researchers conduct research already using technology in learning to facilitate the use of devices in the teaching and learning process. In contrast to a study conducted by Kumar \& Cherono [24] and Ansari \& Tripathi [25] research conducted by both college student subjects, their research results show that mobile learning is not only needed by students but is also needed by students.

The field study results revealed that the school had implemented technology-based learning, as evidenced by the National CBT (Computer Based Test). At the time of observation, it was shown that the majority of students use smartphones, but their use has not been maximized. Students using smartphones are not used to look for information related to learning; from the results obtained, the development of mobile learning media learning is sparked so that students use devices to the maximum.

After conducting field studies, the development of an android learning media continues, which can help students learn independently. Development of teaching media software for Smart Apps Creator. In this software, the researchers designed their media to be developed. In this software, the resulting output can be in the form of .apk .ipa and .exe. In the first stage of development, design, or storyboard for the media will be made, then determine the appearance of learning media. The early development has been carried out, and the finished product is assessed by experts, including media experts and material experts. Own media expert by Informatics Engineering Education lecturer at the Muhammadiyah University of Surakarta. A material expert by a mathematics teacher at SMK Muhammadiyah 1 Sragen. Media experts provide an assessment related to the appearance of the application's feasibility application, while for material experts to assess the material contained in the form, whether it is by basic competencies and core competencies.

The development of instructional media is aimed at testing the effectiveness of learning using mobile learning. In this study, mobile learning is very influential in students' learning motivation so that there is an increase in the value obtained by students. With this media, students can learn more independently wherever and whenever. Like the research conducted by Roohullah Jan et al. [26] and Ekawarna \& Riyadi [27] based on research conducted both have the result that the use of mobile learning in the learning process is more improved than using the conventional method where the teacher explains the material to be conveyed. There is an increase in the value of students.

This learning media has several features, namely material, learning videos, quizzes, and discussion. Quiz has ten questions if students answer the questions correctly, get a value of 10 if one has a value of 0 . At the end of the quiz, values and options for discussion will appear.
In developing this learning media application, there are still many shortcomings. One of which is that if it is installed on a smartphone with a higher resolution than at the beginning of development, the application can sometimes come out on its own so that it disrupts students when using instructional media. Another deficiency in this media's development is that the software used is only free for 30 days, so for more than 30 days to be used, researchers must reinstall the application again so that it can be used.

In addition to the shortcomings, there are advantages to this mobile learning media. In this media, no data package is needed to use so that students can use this learning media more efficiently. Another plus is that this media does not take up much storage memory on the smartphone.

In picture 10, a comparison of learning outcomes is obtained from the pretest and posttest scores. The pretest is done before using learning media. After working on the pretest, students try to use learning media. Students work on the posttest after trying to use learning media. So, it can be concluded that by using mobile learning media, there is an increase in the value of students.

Table 3 is the result of questionnaire grade X students of SMK Muhammadiyah 1 Sragen with a total of 21 people. From the chart above, it can be seen that the average student questionnaire score was 70.119. In classifying the value of acceptability ranges, grade scale, and adjective ratings included in the categories acceptable, grade $\mathrm{C}$, and good, meaning that this learning media can be accepted by students to increase students' learning motivation.

\section{REFERENCES}

[1] N. Saienko and Y. Lavrysh, "Mobile assisted learning for self-directed learning development at technical university: SWOT analysis," Univers. J. Educ. Res., vol. 8, no. 4, pp. 1466-1474, 2020, doi: 10.13189/ujer.2020.080440.

[2] C.-M. Hung, I. Huang, and G.-J. Hwang, "Effects of digital game-based learning on students' self-efficacy, motivation, anxiety, and achievements in learning mathematics," $J$. Comput. Educ., vol. 1, no. 2-3, pp. 151-166, 2014, doi: 10.1007/s40692-014-0008-8.

[3] K. Fabian, K. J. Topping, and I. G. Barron, "Using mobile technologies for mathematics: effects on student attitudes and achievement," Educ. Technol. Res. Dev., vol. 66, no. 5, pp. 1119-1139, 2018, doi: 10.1007/s11423-018-9580-3.

[4] S. Radović, M. Marić, and D. Passey, "Technology enhancing mathematics learning behaviours: Shifting learning goals from 'producing the right answer' to "understanding how to address current and future mathematical challenges," Educ. Inf. Technol., vol. 24, no. 1, pp. 103-126, 2019, doi: 10.1007/s10639-018-9763-x.

[5] M. C. Borba, P. Askar, J. Engelbrecht, G. Gadanidis, S. 
Llinare, and M. S. Aguilar, "Digital Technology in Mathematics Education: Research over the Last Decade," in Proceedings of the 13th International Congress on Mathematical Education, ICME-13 Monographs, 2017, no. 43, pp. 579-582, doi: 10.1007/978-3-319-62597-3.

[6] M. Wijers, V. Jonker, and P. Drijvers, "MobileMath: Exploring mathematics outside the classroom," ZDM - Int. J. Math. Educ., vol. 42, no. 7, pp. 789-799, 2010, doi: 10.1007/s11858-010-0276-3.

[7] Y. Park, "A pedagogical framework for mobile learning: Categorizing educational applications of mobile technologies into four types," Int. Rev. Res. Open Distance Learn., vol. 12, no. 2, pp. 78-102, 2011, doi: 10.19173/irrodl.v12i2.791.

[8] M. C. Borba, P. Askar, J. Engelbrecht, G. Gadanidis, S. Llinares, and M. S. Aguilar, "Blended learning, e-learning and mobile learning in mathematics education," $Z D M-M a t h$ Educ., vol. 48, no. 5, pp. 589-610, 2016, doi: 10.1007/s11858-016-0798-4.

[9] R. Junia Sandy and B. Murtiyasa, "Developing a multimedia-based learning media for learning matrix transformation," J. Phys. Conf. Ser., vol. 1265, no. 1, 2019 , doi: 10.1088/1742-6596/1265/1/012020.

[10] Menteri Pendidikan dan Kebudayaan, Kompetensi Inti dan Kompetensi Dasar Pendidikan Dasar dan Menengah. Republik Indonesia, 2018.

[11] M. Aparna, "Application of Matrix Mathematics," Int. Educ. Res. J., vol. 2, no. 12, pp. 80-82, 2016.

[12] R. Herges, S. Duffield, W. Martin, and J. Wageman, "Motivation and Achievement of Middle School Mathematics Students," Math. Educ., vol. 26, no. 1, pp. 83106, 2017

[13] M. Z. Mokhtar, R. A. Tarmizi, A. F. M. Ayub, and M. D. H. Nawawi, "Motivation and Performance in Learning Calculus Through Problem-Based Learning," Int. J. Asian Soc. Sci., vol. 3, no. 9, pp. 1999-2005, 2013.

[14] B. Murtiyasa, S. Rejeki, R. Setyaningsih, and A. Merdekawati, "Students' Thinking in Solving Geometric Problems Based on PISA Levels," J. Phys. Conf. Ser., vol. 1320, no. 1, 2019, doi: 10.1088/1742-6596/1320/1/012068.

[15] A. Maharani and L. Laelasari, "Experimentation of SPICES Learning Strategies with the Method of Problem Based Learning (PBL) to Build Motivation and the Ability to Think Logically for Vocational School Students," Infin. J., vol. 6, no. 2 , pp. 149-156, 2017, doi: 10.22460/infinity.v6i2.p149156.

[16] A. S. Asmara, H. Hardi, and Y. Ardiyanti, "Contextual
Learning on Mathematical Subjects to Enhance Student Motivation for Learning in Vocational High School," JPI (Jurnal Pendidik. Indones., vol. 8, no. 2, p. 228, 2019, doi: 10.23887/jpi-undiksha.v8i2.13499.

[17] J. Brooke, "SUS-A Quick and Dirty Usability Scale," Usability Eval. Ind., vol. 189, no. 194, pp. 4-7, 1996.

[18] R. Masykur, N. Nofrizal, and M. Syazali, "Pengembangan Media Pembelajaran Matematika dengan Macromedia Flash," Al-Jabar J. Pendidik. Mat., vol. 8, no. 2, p. 177, 2017, doi: 10.24042/ajpm.v8i2.2014.

[19] C. A. Fredyana and Dewanto, "Pengembangan Media Pembelajaran Berbasis Android pada Mata Pelajaran Teknologi Dasar Otomotif untuk Kelas X SMK," $J$. Pendidik. Tek. Mesin, vol. 5, no. 2, pp. 40-46, 2016.

[20] M. A. H. Mohammad, "Mobile Applications' Impact on Student Performance and Satisfaction," Turkish Online J. Educ. Technol., vol. 14, no. 4, pp. 102-112, 2017.

[21] A. Rihandoko, "Pengembangan Media Mobile Learning Appypie Android Berbasis Pemahaman Konsep Peserta Didik Kelas Xi Pada Mata Pelajaran Biologi Di Tingkat Sma/Ma," Universitas Islam Negeri Raden Intan Lampung, 2018.

[22] A. Suen and A. Fung, "Shakespeare in the Apps: Mobile Technology in Education Context," Int. J. Inf. Educ. Technol., vol. 6, no. 9, pp. 731-736, 2016, doi: 10.7763/ijiet.2016.v6.784.

[23] H. Harlis and R. S. Budiarti, "Development of Appypie-based Android Application as a Learning Media about Alga in Monera and Protista Course for Students Majoring in Biology Education," Biodik, vol. 4, no. 2, pp. 114-120, 2018, doi: 10.22437/bio.v4i2.5850.

[24] K. Kumar and L. Cherono, "Mobile Based Learning Application for Campus on Android Platform," Int. J. Comput. Trends Technol., vol. 62, pp. 2231-2803, 2018.

[25] M. S. Ansari and A. Tripathi, "An investigation of effectiveness of mobile learning apps in higher education in India," Int. J. Inf. Stud. Libr., vol. 2, no. 1, pp. 33-41, 2017.

[26] S. Roohullah Jan, F. Ullah, H. Ali, and F. Khan, "Enhanced and Effective Learning through Mobile Learning An Insight into Students Perception of Mobile Learning at University Level," Int. J. Sci. Res. Sci. Eng. Technol., vol. 2, no. 2, pp. 674-681, 2016.

[27] N. A. Ekawarna and R. Riyadi, "The Effectiveness of Android-Based Learning Media with Appy Pie toward Indonesian Economics Subject," Int. J. Eng. Technol., vol. 7, no. 3.30 , pp. $287-288,2018$. 